\title{
Government Spending and Economic Growth in Cameroon
}

\author{
Donald Djatcho Siefu, PhD, Lecturer/researcher \\ University of Yaoundé II, Cameroon \\ Martin Njocke, PhD, Lecturer/researcher \\ Neba Cletus Yah, PhD \\ University of Douala, Cameroon
}

Doi:10.19044/esj.2018.v14n28p68～URL:http://dx.doi.org/10.19044/esj.2018.v14n28p68

\begin{abstract}
Today, the role of government spending which is considered as the main instrument in the promotion of economic development is seen in the public investment budget (PIB). This study analyzes the role of the public investment spending in the economic growth of Cameroon. Specifically, it brings out the effect of Public and Private Investment on GDP growth in Cameroon. The role of the PIB as an instigator of economic growth should be clarified in order to justify government investment expenditure. Many studies have analysed the relationship between government spending and economic growth but the analysis of the composition of government spending and induced economic growth is an aspect of economic analysis which deserves more interest. This study analysis the effect of government investment spending on economic growth in Cameroon going from the components of the $\mathrm{GDP}^{5}$ and using VAR (Vector Auto Regressive) model. Our results show the intervals in which the various components of government spending have an effect on economic growth in Cameroon. We find that the lagged GDP and government investments have a positive effect on growth whereas private investments affect it negatively.
\end{abstract}

Keywords: Economic growth, government spending, investment, Cameroon.

\section{I- INTRODUCTION}

Government spending is traditionally regarded as a factor that stimulates economic growth. At the origin of public finance lies the need to ensure that government spending is supported. Since the mid-80s, the effectiveness of state intervention has been under debate and a movement of

5 Also written GDP in the empirical analysis, the terms GDP and PIB are used in an interchangeable manner 
disengagement created without it being reflected by a significant reduction in the size of government spending.

In June 2016, the OECD suggested that European countries use public investment to stimulate growth: "In many countries, there is a set of manoeuvres enabling the mobilization of budgetary policy to reinforce activity using public investment, particularly because long-term interest rates permit an increase the size of the budget" (OECD, 2016). ${ }^{6}$

Today, the role of government spending, considered as the main instrument in fostering economic development is established by the Public Investment Budget (BIP). States are generally faced with the problem of increasing social charges and the continuous quest for increasingly scarce means for the realization of projects of general interest. This is in line with the Keynesian logic according to which government spending can exert a significant counter cyclical effect on the fundamentals of the economy, particularly on consumption and investment.

At the theoretical level, the classical, Marxist and Keynesian thoughts are opposed. According to classical economists, the interventionism of the State is a source of market disequilibrium due to the crowding-out effects related to the increased national debt and the interest on this debt while the Marxists advocate for an increase in public investment in the face of the outdated infrastructures in order to increase the social supply. For the Keynesians, the State should play a key role in the process of economic growth through government spending.

At the political level, different personalities like Donald Trump, Hilary Clinton or Justin Trudeau in Canada agree to increase government investment spending. In this same reasoning, Larry Summers, former secretary at the American treasury, and Paul Krugman, Nobel Prize in economics, join the IMF to advocate for massive plans of public investment which, through their effect on growth and in the presence of quasi null rates, would be able to finance themselves.

Thus, when the national income drops and private spending decreases, the State should support the economy by carrying out additional spending. This additional spending will increase the effective demand which in turn affects the level of production and employment. It is this multiplier principle which is at the heart of Keynesian thought. However, in a situation of overshooting of the economy, when the national income increases and prices increase or that investment exceeds saving, the State should reduce the pressure by limiting government spending.

6 OECD, 2016, «Stronger growth remains elusive: Urgent policy response is needed», Interim Economic Outlook, February. 
At the empirical level, the controversy at the level of results is even greater. Empirical studies on the relationship between government spending and growth can be grouped into five categories:

- A first category finds that the effect of government spending on economic growth depends on the composition of government spending (Landau [1983]; Romer [1986,1990 ; Barro [1990]; Barro and Sala-imartin [1992,1995]; Levine and Renelt [1992]; Easterly and Rebelo [1993]; Devarajan et al., [1996]; Tanzi and zee [1997]; Kneller, Bleaney and Gemmell [1999]; Knight et al.. [1999]; Fan, Zhang L. and Zhang X. [2002]; Wagstaff [2002]; Nabukpo [2007]; Mansouri [2003]; Savage Schlottman and Wimmer [2006]; Afonso and Furceri [2010]; Chakraborty and Nandi [2011]).

- A second category finds a long and short run relationship between the government spending and economic growth (Ram [1986]; Aschauer [1989]; Morley and Perdikis [2000]; Ashipala and Haimbodi [2003]; Kacou [2004], and Ben Hassad [2006]).

- A third category holds that government spending does not contribute to growth (Kormendi and Meguire [1985]; Easterly and Rebelo [1993]; Agell, Lindh and Ohlsson [1997]; Abizadeh and yousefi [1998]).

- A fourth category finds a bi-directional causality relationship between the two variables (Cheng and Wei [1997]; Ouattara [2007], and a oneway causality from growth towards government spending (Ghali [2000]; Islam [2001]; Aregbeyen [2008]; Chimobi [2009], and Tang 2010).

- Finally, a fifth category on the basis of the components of government spending: government consumption, education, investment, military and health spending have non-linear effects on economic growth and these effects are only positive above a given threshold (Fouopi, Nsi Ella, Epo and Mbomon 2013; N'guessan, 2007).

The question of the role of government spending in the economic growth has therefore been the object of many studies. It's consideration into recent models of endogenous growth sufficiently shows that its efficiency is not unanimous in the eyes of scientists and decision makers.

Why this return of government investment spending into economic debates? The pronounced low level of interest rates, gains in productivity and growth are all factors which act in favour of an increase in government investment spending. Firstly, the costs of financing investments are so low that many projects now have an economic and social output higher than their cost of financing. Secondly, government investment projects enable the putting in place of conditions for a recovery of productivity through education, the diffusion of digital technologies or an increase in mobility. Lastly, these 
government investment projects have a positive impact on short-run activity because of spillover effects.

This study being based on Cameroon, the issue of government spending should be addressed in a concrete and pragmatic manner in order to conceive an effective spending plan in Cameroon, a point of departure of this study in a country in which the relationship between government spending and growth does not seem to be verified as shown in the data of MINEPAT (2017) which shows an increase in the public investment budget from $28.28 \%$ to $29.57 \%$ between 2011 and 2013, with the vice of under-consumption as from the year 2014.

In addition, the financial resources intended for public investment in Cameroon will for the first time exceed 1000 billion CFAF following the launching of the three year plan for the reduction of poverty and the building of sites linked to the organization of the 2016 and 2019 African Nations Cup of football. These resources amounted to 1246 billion CFAF in 2015 (representing $31.2 \%$ of the total amount), and 1525 billion CFAF in 2016, i.e. $36 \%$ of the total budget (MINEPAT, 2017).

Government investment spending affects economic growth in Cameroon through its long-run effects on education, health, theoretical scientific research and physical infrastructures. This is based on the fact that the public investment budget, besides private investment, is one of the engines of economic growth wealth creation. The resources of the public investment budget are massively dedicated to the financing of major structural projects (roads, hydro-electricity dams, Kribi deep-sea port....) as well as social micro-projects (classrooms, bore-holes and wells, health centers) that improve the living conditions of the population.

In Cameroon, the actions to be carried-out converge towards the resolution of the problems of production, distribution and transportation on the basis of the three Musgravian functions of the State which are: the function of allocation of the resources, the function of distribution (redistribution and transfer of welfare) and the function of stabilization (regulation and economic policy). ${ }^{7}$ The carrying out of these missions is done by means of the State budget which includes the set of government income and expenditure. This new approach is primarily reflected through the increased autonomisation of the public investment budget as an instrument for the achievement of the policies of the authorities.

Despite the fact that public investment spending attained 35\% in the total State budget, the target necessary to fuel growth as defined in the GESP is not yet achieved. The IMF recently carried out a detailed study on the importance of government investment. This study shows that after one year, a growth in

7Musgrave (1959) 7 cited by Tsafack Nanfosso in "50 ans de politique économique au Cameroun "p 25-33. 
public investment equivalent to $1 \%$ of the GDP leads to an increase in GDP of $0.4 \%$. After four years, this impact reaches $1.5 \%$ (the IMF, 2014). The share of public investment in the public investment budget of the State of Cameroon witnessed a growth of $124.38 \%$ between 2011 and 2016, bringing to $36 \%$ the share of public investment in the total government spending 2016 (see table 1).

Table 1: The distribution of the general budget expressed as a percentage of the Public Investment Budget (PIB) and the growth rate of the PIB (2011-2016).

\begin{tabular}{|l|c|c|c|c|c|c|}
\hline \multicolumn{1}{|c|}{ Nature of the spending } & $\mathbf{2 0 1 1}$ & $\mathbf{2 0 1 2}$ & $\mathbf{2 0 1 3}$ & $\mathbf{2 0 1 4}$ & $\mathbf{2 0 1 5}$ & $\mathbf{2 0 1 6}$ \\
\hline PIB & 680 & 792,2 & 957 & 1000 & 1150 & 1525,8 \\
\hline Total budget & 2800 & 2571 & 3236 & 3312 & 3746 & 4234,7 \\
\hline Share of the PIB in the budget & $24.3 \%$ & $30.8 \%$ & $29.6 \%$ & $30.2 \%$ & $30.7 \%$ & $36.0 \%$ \\
\hline Growth rate of the PIB & - & $16.50 \%$ & $20.80 \%$ & $4.49 \%$ & $15.00 \%$ & $32.68 \%$ \\
\hline
\end{tabular}

Source: MINEPAT (2017)

Also, it appears that the PIB does not considerably affect growth in Cameroon. Although it has been neglected for long to the benefit of the operational budget which makes up $80 \%$ of the general government budget, the share of the PIB in the state budget increased between 2014 and 2015 where it reached $30 \%$ of the total budget and $36 \%$ in 2016 due to investments in infrastructure. It is within this framework that an increase in the PIB is seen as a necessary measure for the achievement of economic growth.

However, in a quantitative manner and according to the GESP, the growth rate should reach an average of 5.5\% in the 2010-2020 period, underemployment fall from $75.8 \%$ to less than $50 \%$ in 2020 and the rate of monetary poverty from $39.9 \%$ in 2007 to $28.7 \%$ in 2020 .

Ten years after reaching the completion point of the HIPC initiative, the macroeconomic situation is not that which one would have desired. Cameroon did not attain the reference rates of the scenario of the GESP even once in the first five years. In 2011, the real growth rate stood at 4,1\% instead of $4.9 \%$ as required; in 2012, Cameroon attained a growth rate of 4,6 instead of 5,6, between 2013 and 2015, the rates are 5,6\%,5,9\% and 5,8\% instead of a three year average of $7.3 \%$. In addition, the number of the poor increased in absolute value in 2014 relative to 2007, in the labour market "the rate of employment of people older than 15 years reduced by almost 10 points, going from $79,5 \%$ in 2007 to $69,6 \%$ in $2014 " .{ }^{8}$

These results are insufficient given the objectives of the government who significantly increased the PIB to reach 32\% of the state budget in 2013. This brings to mind the question of the correlation between government investment spending and economic growth in Cameroon.

We therefore stipulate the following main research question: What role should government investment spending play in the economic growth of Cameroon? Specifically, this question leads to the following questions: Which

8National report on the millennium development objectives (2015). 
categories of government investment spending positively affect economic growth in Cameroon? And what are the levers of growth that can be activated in order to stimulate the PIB and increase it?

To answer these questions, we organise our reasoning on the following methodological aspects: The objective of this study is to analyse the share of government investment spending in the economic growth of Cameroon. It is a question of showing that government investment spending affects economic growth and increases the wellbeing of the population. The lever of economic growth that instigates the PIB should be identified in order to justify government investment spending.

In order to do this, we adopt the following research hypotheses on government investment spending: Government investment spending has a positive effect on growth in Cameroon. In the same manner, the economic growth of the country is boosted by a higher rate of execution of the public investment budget through public investments.

In line with the interventionist view of government spending which considers that government spending can improve the framework for the creation of wealth and promote growth, we think that the PIB must have as final objective, economic growth in the sense of Simon Kuznets (1966; 1971). There should be an increase in goods more than proportional to the increase in the population. This is an important aspect of this study which intends to reveal the various aspects of the relationship between the public investment budget and growth in Cameroon.

As concerns the methodology, the analysis of the effect of government investment spending on the GDP ${ }^{9}$ is done using a $\mathrm{VAR}^{10}$ model. The specification of the model is inspired by William E. Cullison $(1993)^{11}$. Unlike his model, on the one hand, we limit ourselves to three variables: GDP, government investment spending and private investments. On the other hand, instead of using the growth rates of the GDP, public and private investment spending, we use the logarithm of these variables. The estimated coefficients are thus interpreted as elastic ties. The data used comes from World Development Indicators, 2016. The period of study runs from 1977 to 2014, i.e. 38 years. In the rest of this study, after a short review of the literature (second section), we discuss the methodology in the third section. The fourth section presents the main results and their discussion and the last section the conclusions of the study.

9 Also written GDP in this study, the terms GDP and PIB are used in an interchangeably in this study.

10 Vector Auto Regression

${ }^{11}$ WILLIAM E Cullison (1993), "SAVING MEASURES AS ECONOMIC GROWTH INDICATORs" comtemporary economy policy,: January 1993 Full publication history Pages 1-8 Volume 11, Issue 1 


\section{II- Literature review}

We present the theoretical and empirical debates on the effects of government spending on economic growth.

\section{II.1. Theoretical review of the literature}

The debate on the relationship between the government spending and economic growth is not new. It was the center of the concerns of the classical economists who saw the intervention of the State in the economy through government spending as a source of market disequilibrium. For them, the State should be confined to its regulatory functions of defense, justice and diplomacy and take care of the supply of public services essential to the community and which cannot be provided by private individuals.

This restrictive vision of the State is at the opposite end of Keynesian thought. The Keynesians give the State a major role in the process of the economic growth by the means of government spending. They focus on the multiplier effects associated with the increase in government spending or a reduction in the tax rate. Thus, when the national income drops and private spending decreases, the State must support the economy by increasing government spending. This increase goes to boost the effective demand, which impacts the level of production and employment. On the other hand, when the economy is overheating, the State must reduce the pressure by limiting its spending.

New theories of growth developed after the works of Romer (1986) who insists on the fact that the accumulation of physical capital in a company leads to positive spillover effects on other firms. Romer highlights the importance of research and development which has positive externalities on the rest of the economy. Lucas (1988) justifies the role of investment in human capital in the process of economic growth. In this aspect, the State should finance education expenditure when "the social productivity of the expenditure is higher than the private productivity". Also, the State has to finance public infrastructures (Barro,1990).

These new theories henceforth integrate an explicit analysis of the longterm determinants of the increase in productivity which was formerly ignored by the basic model of Solow [1956]. The variety of the traditional factors of production taken into account in the formalization of the model was extended to include the effects of training, human capital, public infrastructures... The technical conditions of obtaining a truly endogenous growth were not underestimated (constant returns on the combinable factors of production) as well as the positive externalities related to investment in the factors of production and the role of knowledge in the growth of productivity. Thus, endogenous growth models integrate the positive or negative externalities related to the accumulation of knowledge or innovation (Helpman,1992). 
In addition, Barro and Sala-i-Martin (1995) distinguish productive government spending (defense, education, health, transport and communication) from unproductive spending (social security, leisure, economic services).

Going from the above literature, many studies are carried out nowadays to understand if the composition of government spending through the PIB can lead to economic growth.

\section{II.2. Empirical review of the literature}

The results of empirical studies on the causality between government spending and growth remain controversial. These results can be classified in five categories.

In the first category of studies, government spending has a positive effect on economic growth. The positive impact of government spending on economic growth is highlighted by RAM [1986] who studies the impact of the size of the public sector on economic growth (measured by the growth rate of the GDP) for 115 countries in the years 1960-1980. According to this study, the global impact of the size of the public sector on growth is generally positive during this period.

Morley and Perdikis [2000] show the existence of a positive long run effect of overall government spending on growth in Egypt. Reinikka and Svensson (2004) also find that economic growth is significantly explained by government spending in a time series study carried out in Uganda. Using a methodology which differs from the preceding ones, Sahn and Younger (2002) using a microeconomic analysis, find a positive effect of government spending on the evolution of GDP per capita by considering economic agents having specific characteristics of African countries. Also, Kacou (2004), using the Granger test shows that government spending causes growth in the Ivory Coast.

An increase in the national wealth is thus positively related to an increase in government spending by public authorities motivated by a desire to modernize and increase the basic public services for a greater comfort of the populations. However, in the economic literature, government spending does not always have a positive effect on growth.

Oyo and Oshikoya (1995) and Oyo and Shibata (2001) find that a rise in government spending significantly reduces the growth of the GDP per capita in a two sector economy. Folster and Henrekson (2001) study the determinants of economic growth for the period 1970 to 1995 . To avoid selection bias, they retain the wealthiest countries. They use two distinct measurements of the size of the public sector: the "input" measure takes into account the sum of taxes as a percentage of GDP, whereas "output" measure uses the amount of government spending as a percentage of the GDP. The analysis shows a 
negative effect of the size of the public sector on economic growth using the two measures.

In the same manner, Dar and Amirkhalkhali (2002) examine the role of the size of the public sector in the explanation of differences in economic growth rate in 19 OECD countries for the period 1971 to 1999 . The relative size of the public sector is measured as the government spending of the State expressed as a percentage of the GDP. The authors adopt the traditional Solow [1956] model where the growth rate is a function of the accumulation of capital and labour (two main factors of production), as well as the total productivity of factors. The countries are then classified in three groups according to the amount of government spending. The estimates are made using panel data two stage least squares. The results of the study show that the size of the public sector negatively affects economic growth for the complete sample of countries. The specific coefficients are negative and significant at the $5 \%$ level or less for the majority of the 19 countries.

Clements et al. (2003) and Button et al. (2003) hold that while government spending procures satisfaction or utility to households, they reduce the economic growth because of the crowding out effect. This crowding out effect is also highlighted by Ott (2002) in the United States.

The second category finds a bi-directional causality relationship or a one-way causality from growth towards government spending.

Cheng and Wei (19970 find a bi-directional causality between economic growth and government spending in South Korea over the 19541994 period.

In the same manner, Ouattara (2007) finds using causality tests that economic growth and government spending affect each other in the West African Economic and Monetary Union (WAEMU).

Ghali [2000] uses the Granger causality test to show that the hypothesis according to which government spending causes economic growth is rejected in the Tunisian economy. Thus, tax policy aimed at controlling budget deficits proves to be ineffective.

The study by Islam [2001] on American data for the 1929-1996 period strongly supports the one-way causality from growth towards government spending using the Engle-Granger (1987) error correction method.

Tang, Tuck Cheong (2001) finds a one-way causality from the national income towards government spending in the case of Malaysia.

Aregbeyen (2008) finds a one-way causality from the national income towards government spending using Granger causality test for the case of Nigeria and this result is confirmed by Chimobi (2009).

The study by Tang (2010) highlights a uni-directional causality going from the real income towards government health spending and no causality in the opposite direction. 
Akonji, R.D. et al. (2013) study the relationship between government spending and economic growth by testing the law of Wagner and find that the total capital expenditure and the GDP follow the Wagner law through the granger causality test and find a one-way causality.

On the other hand, the global spending for the period and the GDP have a bi-directional causality. But the bond between the global spending for the period and the GDP is stronger.

In the third category of studies, it is the composition of government spending that explains economic growth. According to endogenous growth theorists, government spending can affect economic growth through two main channels.

Through the first channel, they increase the stock of capital of the economy through government investment in economic and social infrastructures or through the investment of public companies. Through the second channel, government spending indirectly affects economic growth by increasing the marginal productivity of the factors of production supplied by the private sector through spending on education, health and other services which contribute to the accumulation of human capital (Tanzi and Zee, 1997).

Devarajan et al., [1996] and Ventelou [2002] distinguish between productive and unproductive government spending and show that the increase in the growth rate does not depend only on the productivity of the two types of spending, but also on the optimal choice of the composition of government spending.

Thus, Devarajan et al. (1996) do not find any significant relationship between growth and the level of spending of public services in the United States. Herrera (1998a) examine the effects of government spending on education on economic growth in the long run,, while resorting to a model of endogenous growth by accumulation of human capital in only one sector. The author finds that the dynamics of growth is impelled by the State, whose choices in the allocation of the budget determine the rhythm of accumulation of human capital.

In the same manner, Dessus and Herrera [2000] arrive at the conclusion according to which government physical capital spending has a positive effect on economic growth. To arrive at this conclusion, they use a panel with data on 29 Latin-American, African and Asian countries observed over an 11 years period, 1981 to 1991. The adopted model appears as a system of simultaneous equations which includes the determinants of the GDP and stocks of public and private capital. The estimation is done using three stage least squares with fixed effects.

Empirical studies on the relationship between government spending and economic growth in African countries lead to contrasted results. The findings of Ashipala and Haimbodi (2003) show two long run relationships 
between the level of economic activity measured by the GDP and government and private investment in Namibia. These long run relationships show on the one hand, that an increase in government investment has a positive effect on economic growth, and on the other that government and private investments are complementary. Mansouri (2003) finds that in Morocco, government capital spending has an effect of drive on private investment and real economic growth. Using a time series model estimated by ordinary least squares; the author shows that government consumption spending crowds-out private investment and slows down economic growth because of wastage.

Dumont and Mesplé-Somps (2000) analyse the impact of government infrastructures on the competitiveness and the growth of the Senegalese economy within the framework of a computable general equilibrium model. They find that an increase in government spending on infrastructures leads to a better commercial performance and economic growth. In the WAEMU countries, Nubukpo (2007) evaluates the impact of government spending on the growth of WAEMU countries from 1965 to 2000. The author uses a model where the real GDP is explained by the gross enrolment in secondary schools, the growth rate of the working population, the share of government spending in the GDP, the index of the terms of trade, real private investment and inflation. Using an error correction model, the author finds that the government spending does not have a significant effect on economic growth in the majority of the economies of the Union. In the long run, the impact of government spending differs by country.

In a study based on causality tests with annual data from 1970 to 2005, Chimobi [2009] finds that there is no long run relationship between government spending on health and education and the national income in Nigeria. However, the author emphasizes that government spending plays a driving role in economic growth.

Afonso and Furceri (2010) show that spending on social contributions and administrative expenditures have a negative effect on growth in European countries while government investment spending through their volume, have a positive effect on growth but, the more this volume is volatile, the lower the level of growth is. They also find that percentage point increase in government spending in terms of GDP would decrease growth by 0.13 percentage points. These authors arrive at the same results as Devarajan et al. (1996) as concerns the effect of capital spending on growth for developing countries; a result that appears surprising if one considers the endogenous growth theories which postulate that this spending is beneficial to the economy because of the externalities which they produce. It is possible to interpret the results of Afonso and Furceri (2010) by the existence of threshold effects, implying that beyond certain threshold, investing public funds in infrastructures is counterproductive if it is done to the detriment of administrative expenditures. 
Nubukpo (2007) also advances, going from his results, the hypothesis according to which there is a non-linear relationship between the size of the State (government spending expressed as a percentage of the GDP) and economic growth.

In the same manner, Fouopi et al. (2013) find a non-linear relationship between government spending and economic growth through the components of government spending, using a Panel Smooth Threshold Regression (PSTR). Their results also specify the margins in which the various components of government spending can have a positive and significant effect on economic growth in the countries of the Central African Economic and Monetary Community (CEMAC).

The fourth category of studies finds that the government spending does not have any effect on growth. The inefficiency of government spending has been highlighted through the theory of political markets. According to Buchanan and Tullock (1961), the State is not the representative of the general interest as it is often considered. These authors show that the authorities are economic agents who seek to maximize their satisfaction through an election or a re-election and that the government decisions are the result of the aggregation of private decisions such as electoral promises. The politicians thus seek to honour electoral promises rather than the efficiency or productivity of government spending. In the same manner, the theory of bureaucracy stipulates that agents or bureaucrats seek to maximize their incomes or power. This leads to an unjustified increase in government spending (Bleralt, 1991); Muller, 2005).

In an empirical study on 98 countries, Barro (1990) finds that the effect of government spending on economic growth is negative. In fact, on the basis of an endogenous growth model, he finds that the components of government spending such as educational, health and security spending do not have statistically significant effects on the level of the economic growth.

Shantayanan Devarajan et al. (1996) apply ordinary least squares to data on 43 countries and find that government spending has a positive and significant effect on economic growth, but that the relationship between the components of government spending and the growth of capital is negative. According to these authors, the excess use of productive spending can be unproductive. These results confirm the poor allocation of government spending in favour of capital expenses.

Dhanasekaran (2001) and Martinez-Lopez (2005) show the very weak correlation existing between government spending and the growth rate of the GDP in India and Spain. Using countries of the Organization of Economic Cooperation and Development (OECD), the results of Dar and Amirkhalkhali (2002) do not make it possible to support the hypotheses according to which 
government spending positively affects economic growth since the coefficients are not statistically significant.

Agell et al. (1999) question the capacity of the usual regression methods to produce reliable conclusions concerning the effects of the public sector on growth. They highlight the most significant limits of these studies in terms of the data and methods, particularly the specification of econometric models. By re-estimating the growth equations of Folster and Hendrekson (1999), they find that the effects of government spending on economic growth are statistically non-significant.

By taking a broader period, Aghion et al. (2007) study the various factors of economic growth using data on a panel of 17 OECD countries for the 1985 to 2003 period. The growth indicator used is the total factor productivity. The study seeks to determine the levers of growth using variables like human capital and rigidity on the goods and labour markets. The size of the public sector intervenes in the estimates as a component of rigidities on the goods and labour markets. The results of this study do not make it possible to conclude that the public sector has significant positive effects on economic growth.

Nubukpo (2003) using a standard growth model concludes that in the short run, the total government spending does not have significant effects on growth in the majority of WAEMU countries. In the long run, the effect of the global government spending on growth differs largely between countries. The authors also conclude that government consumption spending exerts an overall negative effect on the GDP in the short and long-run in the UEMOA and that government capital spending has a positive effect in the long run on the GDP of the UEMOA.

Keho (2008) finds that in the long run, there is an absence of causality between the GDP, government spending and the indicators of education.

Okoro A.S. (2013) in a study on government spending in Nigeria concludes that in the long run, there is an equilibrium between government spending and economic growth and that the short-run dynamics adjusts the long-run equilibrium at a rate of $60 \%$ per annum.

Ales Kuhar et al. (2005) in an input-output model in a study in the periphery of Slovenia arrives at results which show that government funds can stimulate economic growth in the peripheries of Slovenia. However, the comparison at the national level shows that there are backward regions. Ali Sulieman (2014) in a study on government expenditure in Jordan finds that education and capital spending does not lead to economic growth because education is expensive. However, expenditure in health and economic affairs impact on economic growth.

Lastly, the fifth category of studies treats government spending as a driver of growth and the competitiveness strategy of an economy. All spending 
related to publicity or marketing, especially in the traditional sectors make it possible to increase or preserve market shares in a competitive environment. This makes it possible to increase the domestic or external demand which is the engine of economic growth. Moreover, this makes it possible to increase the popularity of a company and thus increase its non-price competitiveness.

The training, research and development spending enables companies not only to maintain and improve their level of technology, but also carry positive externalities. Followers of the endogenous growth theory (Robert Solow 195ã, 1956b, 2000, 2002; Robert Barro 1995,1998, 2002, 2004; Robert Barro et al., 2003; Robert Lucas Junior 1969; 1975, 1977'2) and the macroeconomists (Bernard Guerrien, 2015; Benchimol and J. Fourcans, 2012) highlight the role of training in the explanation of differences in rate of growth between countries.

Guessan (2007) in a simple accelerator model in which it is supposed that the technology of production is characterized by a fixed relationship between the stock of desired capital and the level of production reaches results that make it possible to establish the existence of an effect of drive of government investment on private investment in the Ivory Coast, Togo, and to a lesser extent, in Niger. However, the effect of drive could not be highlighted in Benin, Burkina Faso, Mali, and Senegal. The decomposition of government spending proves to be important in the dynamics of the growth in the WAEMU union.

It is undeniable that material or immaterial investments promote economic growth, not only as the second component of domestic demand and a flow of expenditure leading to a distribution of incomes, but they increase supply and thus stimulate demand.

In addition, any investment comprises a great part of uncertainties on their profitability. This is why managers take into account their financial means and the state of the economy. Thus, economic growth also affects investment and the public investment budget.

The absence of consensus in the results of the studies above leads us to consider that a linear approach is probably not adapted to the analysis of the relationship between government spending and economic growth. This leads us to consider using a more stable econometric modeling the VAR (Vector Auto Regressive) model inspired by William E. Cullison (1993). This model is an econometric framework that enables the taking into account of this nonlinearity.

12Lucas, R. E. Jr (1977), "Understanding Business Cycles", Carnegie Rochester Series Conference on Public Policy, vol. 5, pp. 7-46. It is in these articles that he exposes his theory of cycles and his famous criticism, known as the Lucas critique 


\section{METHODOLOGY}

In the literature, many variables have been used to capture economic activity. As a proxy of economic activity, researchers generally use either the Gross domestic product (GDP), or the Gross national product (GNP) and in certain cases, the national income or industrial production. In the case of this study, we use the GDP.

The analysis of the effect of government investment spending on economic growth in Cameroon is done in this study on the basis of the components of the GDP ${ }^{13}$ using a VAR (Vector Auto-Regression) model. The VAR specification is simple and easy to estimate. It makes it possible to build a certain number of tools which prove to be useful in the making of forecasts, the study of dynamic relationships between variables and the propagation of shocks within an economic system. The study that popularised this VAR approach is the article by Sims (1980). ${ }^{14}$

The specification of our model is inspired by William E. Cullison (1993). ${ }^{15}$ Unlike this author, on the one hand, we limit ourselves to three variables: GDP, government investments (InvPub) and private investments (InvPri). Going from the model: $\mathrm{Y}=\mathrm{C}+\mathrm{I}+\mathrm{G}+(\mathrm{X}-\mathrm{M})$ Where: $\mathrm{Y}$ : GDP; $\mathrm{C}$ : consumption; I: private investment; G: government spending; $\mathrm{X}$ : exports; $\mathrm{M}$ : imports.

Also, instead of using the growth rates of the GDP, government and private investments, we use the logarithm of these variables. The estimated coefficients are thus interpreted as elasticities.

In fact, $\mathrm{yt}_{\mathrm{t}}=(\mathrm{y} 1 \mathrm{t}, \ldots, \mathrm{ykt})$, follows a Vector auto-regressive process of order p, or $\operatorname{VAR}(\mathrm{p})$, if:

$\mathrm{y}_{\mathrm{t}}=\mathrm{c}+\Phi_{1 \mathrm{y}_{\mathrm{t}-1}}+\Phi_{2} \mathrm{yt}_{\mathrm{t}-2}+\cdots+\Phi_{\mathrm{p} \mathrm{y}_{\mathrm{t}} \mathrm{p}}+\mathrm{u}_{\mathrm{t}}$

On the basis of this equation, our model is specified with our three key variables:

$$
\begin{aligned}
& \text { GDP }=\mathrm{F}(\text { Invpub, InvPri) such that: } \\
& \mathrm{GDP}_{\mathrm{t}}=\mathrm{c}+\Phi 1 \operatorname{InvPub}_{\mathrm{t}}+\Phi 2 \operatorname{InvPri}+\mu_{\mathrm{t}}, \quad(1)
\end{aligned}
$$

For the econometric equation, we need an error term $(\mu)$ and this error term makes GDP a random variable and since we have three variables, we are in the presence of a VAR model of order $p \geq 2$. We suppose initially that the studied processes are stationary.

13 Also written GDP in the empirical analysis, the terms GDP and PIB are used in an interchangeably

${ }^{14}$ Sims (1980), Macroeconomics and reality, published in 1980 in the Econometrica journal

15 Cullison, William (1993), Public Investment and Economic Growth, FRB Richmond Economic Quarterly, vol. 79, No 4, Fall 1993, pp. 19-33. Available At SSRN: https://ssrn.com/abstract=2129245 
By linearizing, we obtain:

$\log \mathrm{GDP}_{\mathrm{t}}=\mathrm{C}+\Phi_{1} \operatorname{LogInvPub}+\Phi_{2} \operatorname{LogInvPrit}+\mu_{\mathrm{t} .}(2)$

With, $\mathrm{C}=$ the constant and $\Phi_{1}, \Phi_{2}=$ parameters. InvPub, InvPri respectively stand for the public investments and Private investments.

\section{III.1- Data}

The data used comes from World Development Indicators 2016 (WDI, 2016). The period of study goes from 1977 to 2014, i.e 38 years.

\section{III.2- Descriptive Statistics of Variables}

Table 2 below shows the descriptive statistics of the variables used. Figure 1 presents the evolution of the variables of study over 1977-2014 period. We observe that this evolution shows the main phases of the economic evolution of Cameroon.

Table 2: Presentation of the descriptive statistics of the variables used

\begin{tabular}{|l|l|l|l|l|}
\hline Variables & Mean & $\begin{array}{l}\text { Standard } \\
\text { deviation }\end{array}$ & Minimum & Maximum \\
\hline Log(PIB $)$ & 10,961 & 0,122 & 10,669 & 11,2 \\
\hline Log(Inv_Pub) & 9,485 & 0,209 & 9,163 & 10,042 \\
\hline Log(Inv_Pri $)$ & 10,144 & 0,164 & 9,874 & 10,46 \\
\hline
\end{tabular}

Source: Authors using Stata 13 and WDI 2016.

Figure 1: Evolution of the logarithm of the GDP, public investments and the private investments

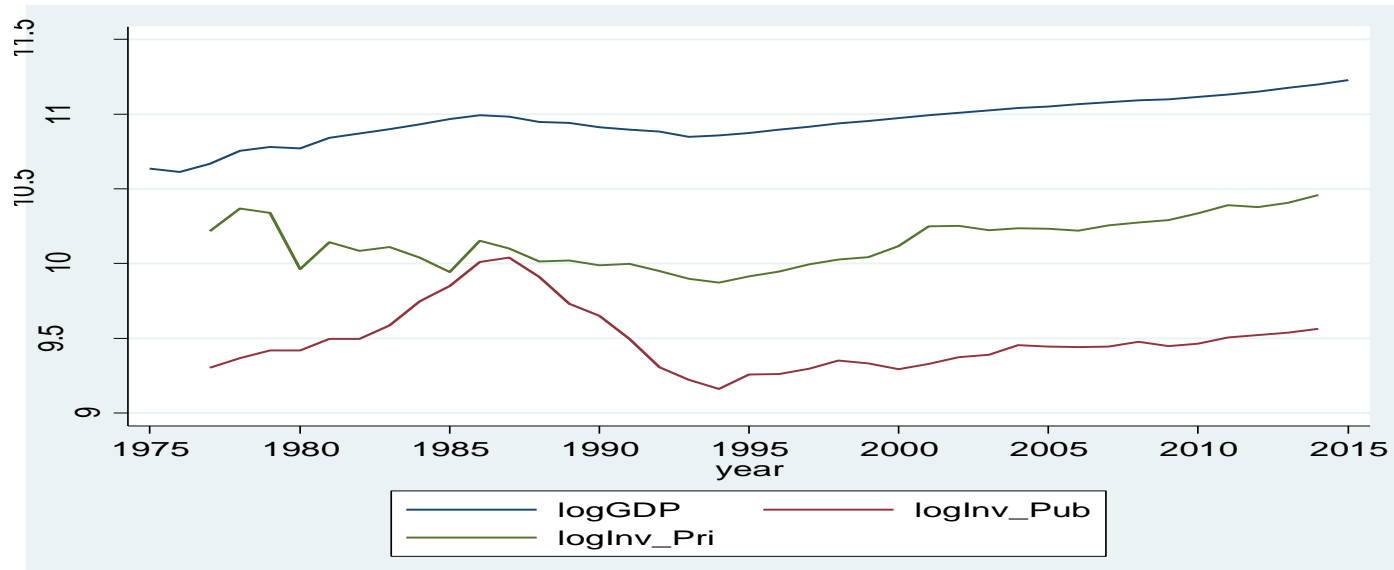

Source: Authors using Stata 13 and WDI 2016.

The first phase known as that of fast economic expansion goes from 1977 with the beginning of oil exploitation at the beginning 80s. During this period, the country records high growth rates. The figure shows that this period is also characterized by a strong expansion of public investments. The second phase known as the phase of crisis goes from 1986 to 1994. During this phase, the country records negative growth rates and a large drop in public 
investments. The third phase which is that of recovery starts in 1994 when the country starts registering positive GDP growth rates. After 1994, the curve of government investments regains a positive slope. Figure 1 thus makes it possible to reveal the link between the evolution of the GDP and that of government investments.

Private investments do not show an evolution related to that of government investments and the GDP. Its evolution can be analyzed in two phases. The first which goes from 1977 to 1994 during which the curve of the private investments presents a downward trend. The second phase starts in 1994, during which the curve of the private investments has a positive slope.

\section{III.3- Estimation of the VAR}

The methodology falls under the line of studies using unit root tests which enable researchers to determine the existence of non-stationnarity, the Augmented-Dickey-Fuller (ADF) test, cointegration tests, and Granger causality tests. Studies on the same topic have been carried out by other economists who do not take into account private investments. In this study, we integrate this aspect.

The estimation of our VAR model starts with the unit root tests. Table 3 below summarizes the results of these tests.

Table 3: Summary of the unit root tests

\begin{tabular}{|c|c|c|c|}
\hline Variables & $\log (\mathrm{GDP})$ & $\log \left(\mathrm{Inv} \_\right.$Pub $)$ & $\log ($ Inv_Pri) \\
\hline Level of integration & $\mathrm{I}(1)$ & $\mathrm{I}(1)$ & $\mathrm{I}(1)$ \\
\hline
\end{tabular}

Source: Authors using Stata 13 and WDI 2016.

Secondly, we determine the optimal number of lags. For this, three criteria of information are generally used: the Aikake information criterion (AIC), the Schwarz bayesan information criterion (SBIC) and the Hannan and Quinn (HQIC) information criterion. Two of these three criteria (HQIC and SBIC) indicate an optimal number of lags of 2 (see table 3 ). We thus retain 2 as the number of optimal lags.

Table 4: Determination of the order of the VAR

Selection-order criteria
Sample: $1981-2014$
\begin{tabular}{|c|cccccccc|}
\hline lag & LL & LR & df & $p$ & FPE & AIC & HQIC & SBIC \\
\hline 0 & 79.1418 & & & & $2.3 e-06$ & -4.47893 & -4.433 & -4.34425 \\
1 & 195.466 & 232.65 & 9 & 0.000 & $4.1 e-09$ & -10.7921 & -10.6084 & -10.2534 \\
2 & 228.326 & 65.72 & 9 & 0.000 & $1.0 e-09$ & -12.1956 & $-11.8741^{*}$ & $-11.2529 *$ \\
3 & 238.479 & $20.306 *$ & 9 & 0.016 & $1.0 e-09 *$ & $-12.2635 *$ & -11.8042 & -10.9167 \\
4 & 244.162 & 11.365 & 9 & 0.251 & $1.3 e-09$ & -12.0683 & -11.4712 & -10.3175 \\
\hline
\end{tabular}

source: Authors using Stata 13 and WDI 2016. 


\section{IV-RESULTS AND INTERPRETATIONS}

The results of the VAR estimation are presented in table 5 below:

Table 5: Estimation of the VAR model

\begin{tabular}{|c|c|c|c|}
\hline & $(1)$ & $(2)$ & $(3)$ \\
\hline & D_logGDP & D2_logInv_Pub & D_logInv_Pri \\
\hline VARIABLES & & & \\
\hline L2D.logGDP & $0.616^{* * *}$ & -0.690 & 0.744 \\
\hline & $(0.144)$ & $(0.646)$ & $(0.594)$ \\
\hline L2D2.logInv_Pub & $0.0858^{* *}$ & -0.0304 & 0.0327 \\
\hline & $(0.0405)$ & $(0.181)$ & $(0.167)$ \\
\hline L2D.logInv_Pri & $-0.115 * * *$ & 0.0690 & -0.0774 \\
\hline & $(0.0339)$ & $(0.151)$ & $(0.139)$ \\
\hline Constant & $0.00557 *$ & 0.00882 & 0.00598 \\
\hline Observations & $(0.00315)$ & $(0.0141)$ & $(0.0129)$ \\
\hline R2 & 34 & 34 & 34 \\
\hline & 0.431 & 0.035 & 0.047 \\
\hline & Standard errors in brackets & \\
\hline & $* * * \mathrm{p}<0.01, * * \mathrm{p}<0.05, * \mathrm{p}<0.1$ & \\
\hline
\end{tabular}

Source: Authors using Stata 13 and WDI 2016.

These results show that the lagged GDP and government investments have a positive effect on growth whereas private investments affect it negatively (see column 1 ). These results indicate that a $1 \%$ increase in the lagged GDP increases the GDP by $0,6 \%$. An $1 \%$ increase in government investments induces an increase in the GDP of $0,09 \%$. A $1 \%$ increase in private investments induce a reduction of the GDP of $0,11 \%$. The negative effect of private investments on the GDP is unusual but can be justified by the downward trend observed between 1977 and 1994, thus inhibiting the economic growth of the country.

The second and the third columns show that there is no effect of the GDP and the private investments on public investments on the one hand (column 2). In addition, that there are no effects of the GDP and government investments on private investments. The Granger causality tests (table 6) confirm these results. They show that there is a $96,6 \%$ possibility that government investments affect the GDP $3,4 \%$ chance that it does not have an effect on GDP) and $99,9 \%$ possibility that private investments affect the GDP $(0,1 \%$ of chance that it does not have an effect on GDP). 
Table 6: Granger causality test

Granger causality Wald tests

\begin{tabular}{|rr|rrr|}
\hline Equation & Excluded & chi2 & df Prob > chi2 \\
\hline D_logGDP & D2.logInv_Pub & $\begin{array}{l}4.4822 \\
11.623\end{array}$ & $\begin{array}{l}0.034 \\
0.001 \\
\text { D_logGDP }\end{array}$ & D.logInv_Pri \\
D_logGDP & ALL & 12.923 & 2 & 0.002 \\
\hline D2_logInv_Pub & D.logGDP & 1.1395 & 1 & 0.286 \\
D2_logInv_Pub & D.logInv_Pri & .20764 & 1 & 0.649 \\
D2_logInv_Pub & ALL & 1.1405 & 2 & 0.565 \\
\hline D_logInv_Pri & D.logGDP & 1.568 & 1 & 0.211 \\
D_logInv_Pri & D2.logInv_Pub & .03834 & 1 & 0.845 \\
D_logInv_Pri & ALL & 1.6734 & 2 & 0.433 \\
\hline
\end{tabular}

Source: Authors using Stata 13 and WDI 2016.

On the other hand, there is a $28,6 \%$ possibility that the GDP does not have an effect on government investments and $64,9 \%$ possibility that private investments do not have an effect on public investments. There is a $21,1 \%$ possibility that the GDP does not have an effect on private investments and $84,5 \%$ possibility that government investments do not have an effect on private investments.

The analysis of the impulse response functions (figure $\mathbf{2}$ in appendix) show possible that the effect of government and private investments on the GDP is not permanent. It is temporary and of very short duration. In fact, the impact on growth of a shock on government or private investments becomes marginal at the end of two or three years. These results enable us to better appreciate the impact on the GDP, public investments public and private investments.

As concerns the impact on the GDP, a shock on the GDP has an impact of $1 \%$ at the initial period. A shock on the private investments or government investments would have a null impact on the GDP in the initial period and period one.

As concerns the impact on private investments, a shock on private investment would have an impact of 5\% in the initial period. A shock on the GDP would have an impact of $3 \%$ on private investment in the initial period. And a shock on government investments would have an impact of $1,6 \%$ on private investments in the initial period.

Concerning the impact on government investments, a shock on government investment would have an impact of $6 \%$ in the initial period. A shock on the GDP would have an impact of $3 \%$ on government investments in the initial period. And a shock on private investments would have a null impact 
on government investments at the initial period and the first period. Table 7 and figure 3 (see appendix) enable us to appreciate the stability of our VAR model.

We observe that the eigenvalues are all lower than one. In other words, they all are inside the unit circle (see figure 3 ). We can thus conclude on the stability of our VAR model.

An analysis of the statistics in the tables show that the government investment spending in Cameroon largely exceeds the threshold of 33,9\% from which the sensitivity of growth becomes negative.

\section{CONCLUSION AND RECOMMENDATIONS}

It proved to be significant in this study, to analyze the impact of government investment spending on economic growth in Cameroon. This study is justified in a context where the country benefitted from the cancellation of the debt through the HIPC initiative. Moreover, in the face of the millennium development objectives, we notice that the insufficiency and non-availability of control engineers constitute two different issues for the country. "We find that more financial needs to be granted to sub-contractors who have to follow-up the execution of contracts but who always do not have the means of follow-up" MINEPAT (2013). ${ }^{16}$ Opacity in the execution of projects by the decentralized authorities comes to add to these ills. As for the corrupt contractors, they are being judged along with those who abandon contracts or execute them badly.

Besides these exogenous factors, the sector of public contracts of the country suffers from several ills whose main diagnosis is centered on badgovernance, administrative bureaucracies and the approximate application of texts governing public contracts.

According to the growth and employment strategy paper (GESP), Cameroon must use the public investment budget as a major tool boost its economy. Previous decades testify to the many reforms which produced and continue to produce changes in the Cameroonian economy. After a theoretical and descriptive analysis, we find that increase in government investments lead relatively stable and positive phase of economic growth and downward movements correspond in their turn to negative growth rates.

This result lets predict a positive contribution of government investment expenditure to economic growth. To measure in a formal way this contribution, we use an appropriate economic model. The great challenge in the public investment budget (PIB) is at two levels: the elaboration and application of the growth and employment strategy paper (GESP) and the application of program budgets.

16Colloquium on the execution of the public investment budget organized on August 20, 2013 by MINEPAT 
In this line, it is no longer a question of doing what is authorized with the public funds, but one of doing it in the best possible manner at lowest cost. It is thus a question of mastering the use of public funds to provide a service adapted to the expectations of citizens on the basis of objectives and predefined indicators of budgetary performance set in terms of investment. This requires an efficient system of control of government investment spending. The approach to the concept of government investment in the Cameroonian context should therefore be a progressive and institutional learning one, interactive and permanent, as well as a continuously improved process.

In this context, the Cameroonian government should put in place actions destined to mitigate these various insufficiencies. These actions can only be effective if studies on disaggregated data (that distinguish investments in physical infrastructures from social investments) make it possible to take effective action. Furthermore, the private public partnership should no longer an illusion, but a reality because it is obvious that today these tools are efficient only when the framework and environment correspond with the necessary data, the human resource factor having a priority.

We conclude this study by stating some principles:

- The principle of learning; experts and civil servants in charge of the budget must hold in a permanent manner, periodic recycling of the executives in public finance.

- The principle of coherence. This principle preaches the good management of the State budget which suffers from a major defect: that of inconsistency both at the level of the administrators of the various ministries in charge of this tool and at the level of legislations in place and even in the organization of public finance in general. Management requires good governance, and also consists in administering and forecasting. It is in this wise that government action must imperatively be in adequacy with the social background, and there should exist areas for structuring or of production of coherence within the administrative and political system. The greatest efficiency of government spending is achieved when the integration and harmony of the various actors is reached.

- Then comes the principle of clarity. This principle lies at the center of the system of budgetary control because it is the politician who holds the leitmotiv of government policies and the management of the public investment budget. It is necessary that the competences of each actor intervening in the sector of the investment budget are clearly defined, identified and specified within the framework of the government investment spending. 
- Lastly, comes the principle of regulation which constitutes a fundamental element in the management of government investment spending. It is the item which maintains the trajectory of government investment spending in the process of economic growth.

\section{References:}

1. ABIZADEH, SOHRAB and YOUSEFI, MAHMOOD (1998), "An Empirical Analysis of South Korea's Economic Development and Public Expenditures Growth », Journal of Socio-Economics vol.27, p.687-700.

2. AFONSO A., and FURCERI D. (2010), «Government Size, Composition, Volatility and Economic Growth», European Journal of Political Economy, Vol. 26, No. 4, pp. 517-532.

3. AGELL J., LINDH T. et OHLSSON H. (1999), "Growth and the Public Sector: a Reply », European Journal of Political Economy, Vol. 15, p. $359-366$.

4. ALEXANDER, X. (1990) « The Impact of Defence Spending on Economic Growth », Defence Economics,vol.2, N 1, p. 39-55.

5. Analyse de Causalité », Cellule d'Analyse de Politiques Economiques du CIRES (CAPEC), LPE N ${ }^{\circ} 56$, p.1-4.

6. AREGBEYEN, O. (2008) «Cointegration, Causality and Wagner's Law: A Test for Nigeria ", Central Bank of Nigeria Economic and Financial Review, Vol.44, N², p.1-17.

7. ARROW K.J. and KURTZ (1970), PublicInvestment, the Rate of Return and Optimal Fiscal Policy, John Hopkins University.

8. ARROW, K.J. and Li J.E. (1993), «A Note on the Peace Dividend and Real location of Knowledge Skills », in Brauer, J. et Chatter M. jieds, Economic Issues of Disarmament, pp . 26-32, Macmillan, Londres.

9. ASCHAUER D. A. (1989), «Is Public Expenditure Productive?», Journal of Monetary Economics, Vol.23, N², p. 177-200.

10. ASHIPALA J. and HAIMBODI N. (2003), « The Impact of Public Investment on Economic Growth in Namibia », Working Paper, No. 88, NEPRU;

11. BUCHANAN J. et TULLOCK G. (1961), Calculus of Consent. Ann Arbor: University of Michigan Press

12. BALDACCI E., CLEMENTS B., GUPTA S. and CUI Q., (2008) « Social Spending, Human Capital, and Growth in Developing Countries», World Development, Vol.36, №8, p.1317- 1341.

13. BANQUE MONDIALE (2006), Rapport Annuel. Washington : Banque Mondiale. 
14. BARRO R. (1995), "Capital Mobility in Neoclassical Models of Growth with Gregory Mankiw and Xavier Sala-i-Martin”, American Economic Review 85, Mar., 103-115.

15. BARRO R. (2002), Nothing Is Sacred: Economic Ideas for the New Millennium, Cambridge, MIT Press, , 184 p.

16. BARRO R. (1998), Determinants of Economic Growth: A CrossCountry Empirical Study, Cambridge, MIT Press, (réédition), 157 p.

17. BARRO R.J. et SALA-I-MARTIN (1992), « Public Finance in Models of Economic Growth », Review of Economic Studies, Vol. 59, N 4, p. $645-661$.

18. BARRO R.J., (1990), « Government Spending in a Simple model of Endogenous growth », Journal of Political Economy, Vol. 98, N 5, p. $103-125$.

19. BARRO R.J., (1991), « Economic Growth in a Cross Section of Countries », Quarterly Journal of Economics, Vol. 106, N², p. 407 443.

20. BARRO R.t et Xavier Sala-i-M. (2003), Economic Growth, Cambridge, MIT Press, (2e édition), $672 \mathrm{p}$.

21. BEAC (2010), Rapport Annuel de la Banque des Etats de l'Afrique Centrale

22. BEN S. et HASSA M., (2006), « Efficience du Financement des Services Publics et Croissance Economique dans les pays en développement : Analyse en coupe transversale », Journées Scientifiques du Réseau «Analyse Economique et Développement », $37 \mathrm{p}$.

23. BENCHIMO1, J., Fourçans A. (2012), "Money and risk in a DSGE framework: A Bayesian application to the Eurozone » Journal of Macroeconomics, vol. 34, pp. 95-111.

24. BENHABIB J. et Speigel M., (1994), «The Role of Human Capital in Economic Development: Evidence from Aggregate Cross-Country », Journal of Monetary Economics, Vol. 34, N², p. 143-173.

25. BLEART P.A. (1991), «Théorie du Marché Politique et Rationalité des Politiques Publiques », Revue Française de Science Politique Vol. 41, No. 2, p. $235-263$.

26. BUTTON K., STOUGH R., HIGANO H. and NIJKAMP P., (2003), Telecommunication, Travel and Location,Edward Elgar Publishing Limited, 208 p.

27. CHAKRABORTY C. et NANDI B.,(2011), « 'Mainline' Telecommunications Infrastructure, Levels of Development and Economic Growth: Evidence from a panel of developing Countries», Telecommunications Policy, Vol.35, N5,p. 441-449. 
28. CHENG S. et WEI T., (1997), "Government Expenditures and Economic Growth in South Korea: A VAR Approach »; Journal of Economic Development, Vol.22, $\mathrm{N}^{\circ} 1$, p. 11-24

29. CHIMOBI O.P. (2009), "Government Expenditure and National Income: a Causaliy Test for Nigeria ", European Journal of Economic and Political Studies, Vol. 2, N. 9, p. 1-12.

30. China: The Role of Public Investments », Research Report 125, International Food Policy

31. CHOW G.C., (1960), « Tests of Equality between Sets of Coefficients in Two Linear Regressions », Econometrica, Vol. 28, N. 3, p. 591 605.

32. CLEMENTS B., BHATTACHARYA R. et NGUYEN T.Q. (2003), « External Debt, Public Investment and Growth in Low-Income Countries », IMF Working Paper, No. 03/249, p. 1 -25.

33. COLlETAZ G. et HURLIN C., (2006), " Threshold Effects in the Public Capital Productivity: An International Panel Smooth Transition Approach», Université d'Orleans, LEO working paper, $\mathrm{N}^{\circ} 1 / 2006$. Compétitivité et la Croissance : une analyse en EGC appliquée au Sénégal », DIAL, DT/2000/08.

34. CULLISON William E. (1993), "SAVING MEASURES AS ECONOMIC GROWTH INDICATORs" comtemporary economy policy, : January 1993 Full publication history Pages 1-8 Volume 11, Issue 1

35. DAR A. et AMIRKHALKHALI S. (2002), « Government Size, Factor Accumulation and Economic Growth: Evidence from OECD Countries ", Journal of Policy Modeling, Vol. 24,N²7-8, p. 679-692.

36. DESSUS S. et HERRERA R. (2000), « Public Capital and Growth: a Panel Data Assessment ", Economic Development and Cultural Change, Vol. 48, $\mathrm{N}^{\circ} .2$, p. 407-418.

37. DEVARAJAN S., SWAROOP V. et HENG-FU (1996), "The Composition of Public Expenditure and Economic Growth », Journal of Monetary Economics, Vol. 37, N², p. 313 -344.

38. DHANASEKARAN K. (2001), " Government Tax Revenue, Expenditure and Causality: the Experience of India », India Economic Review, Vol. 36, $\mathrm{N}^{\circ}$ 2, pp. $359-379$.

39. DIAMOND J.,(1989), « Government Expenditure and Economic Growth: An Empirical Investigation », Fiscal Affairs Department Working Paper, $\mathrm{N}^{\circ} 45$, International Monetary Fund.

40. DUMONT J-C, MESPLE-SOMPS S., (2000), « L'Impact des Infrastructures Publiques sur la

41. EASTERLY W. et REBELO S., (1993), « Fiscal Policy and Economic Growth: An Empirical 
42. ENGLE R.F. et GRANGER C.W.J., (1987), Co-integration and Error Correction:

43. Evidence from Cross-Section and Time-series data », The American Economic Review, Vol. 76, No. 1, p. 191 -203.

44. FAN S., ZHANG L. X., et ZHANG X. B., (2002), « Growth, Inequality, and Poverty in Rural

45. FMI, (2014), «Le moment est-il propice à une relance des investissements dans les infrastructures? Les effets macroéconomiques de l'investissement public ».

46. FOLSTER S. et HENREKSON M., (2001), "Growth Effects of Government Expenditure and Taxation in Rich Countries », European Economic Review, Vol. 45, N8, p. $1501-1520$.

47. FOUOPI C. et al, (2013) «Dépenses publiques d'investissement et croissance économique en CEMAC » premier colloque de l'association d'économie théorique et applique.

48. GEMMEL N., KNELLER R. et SANZ I., (2008), " Foreign Investment, International Trade and the Size and Structure of Public Expenditure », European Journal of Political Economy, Vol. 24, N²1, p. $151-171$.

49. GEMMELL N. (1996), «Evaluating the Impact of Human Capital Stocks and Accumulation on Economic Growth: Some New Evidence», Oxford Bulletin of Economics and Statistics, vol. 58, N 1 , p. 9-28.

50. GHALIK, (2000), «Export Growth and Economic Growth: The Tunisian experience», Journal of King Saud University, Administrative Sciences, Vol.12, N², p.127-140.

51. GONZALEZ A, TERRASVIRTA T, DICK VAN DIJK (2005), « Panel Smooth Transition Regression Model», University of Technology Sydney.

52. GUERRIEN B. (2015), «Une brève histoire de macroéconomie » », bernard.guerrien.com

53. HANSEN B., (1999), «Threshold Effects in Non-Dynamic Panels: Estimation, Testing and Inference», Journal of Econometrics, vol. 93, $\mathrm{N}^{\circ} 2$, p 345-368.

54. HANUSHEK E. A et KIMKO D. D. [2000], «Schooling, Labor Force Quality, and the Growth of Nations»,American Economic Review, vol. 90, N5, p. 1184-1208.

55. HELPMAN E. (1992), «Endogenous macroeconomic growth theory » European Economic Review, Elsevier, vol. 36, N²-3, p.237-267.

56. HERRARA R., (1998a), « Dépenses Publiques d'Education et Capital Humain dans un Modèle Convexe de Croissance Endogène », Revue Economique, Vol. 49, N. 3, p. $831-844$. 
57. HERRARA R., (1998b), « Dépenses Militaires : Quels Effets sur les Finances Publiques et la Croissance Economique ", Revue d'Economie Politique, Vol. 108, N. 4, p. $503-530$.

58. HODGES R., (2005), «Governance and the Public Sector», Edward Elgar Publishing Limited, Series No.6, p. 1152.

59. HUANG C. and MINTZ A., (1991), "Defence Expenditures and Economic Growth: The Externality Effects», Defence Economics, Vol. $3, \mathrm{~N}^{\circ} 1$, p. 35-40.

60. Investigation », Journal of Monetary Economics, Vol.32, p. 417-458.

61. ISLAM A., M., (2001), "Wagner's Law Revisited: Cointegration and Exogeneity Tests for the USA », Applied Economics Letters, Vol.8, $\mathrm{N}^{\circ} 8$, p. 509-515.

62. JEVONS Stanleys W. (1871), Theory of Political Economy Harvard University Press, Cambridge, Massachusetts

63. JEVONS Stanleys W. (1874), The Principle of Science : A treatise on Logic and Scientific Method Harvard University Press, Cambridge, Massachusetts

64. JEVONS Stanleys W. (1876), Money and the Mechanism of Exchange Harvard University Press, Cambridge, Massachusetts

65. JEVONS Stanleys W. (1882), The State in Relation to Labour Harvard University Press, Cambridge, Massachusetts

66. KACOU (2004), « Dépenses Publiques et Croissance Economique en Côte d'Ivoire : une

67. KNELLER R., BLEANEY M.F. et GEMMEL N., (1999), « Fiscal Policy and Growth: Evidence from OECD Countries », Journal of Public Economics Vol.74, $N^{\circ} 2,171-190$.

68. KNIGHT M., LOAYZA N. et VILLANUEVA D., (1995), « The Peace Dividend: Military Spending Cuts and Economic Growth », International Monetary Fund WorkingPapers, Middle Eastern Department, $n^{\circ}$ 95-53, mai.

69. KORMENDI R.C. et McGUIRE P. G., (1985), Macroeconomic Determinants of Growth: Cross-Country Evidence. Journal of Monetary Economics, Vol.16, $\mathrm{N}^{\circ} 2, \mathrm{p} .141-63$.

70. KUZNETS S. (1955), "Economic Growth and Income Inequality", The American Economic Review, vol. 45, $\mathrm{n}^{\mathrm{o}}$ 1, p. 1-28,

71. KUZNETS S. (1961), Capital in the American Economy: Its Formation and Financing, Princeton University Press, Princeton,

72. KUZNETS S. (1966), Modern Economic Growth: Rate, Structure, and Spread, Yale University Press, New Haven, Connecticut,

73. KUZNETS S. (1971), Economic Growth of Nations: Total Output and Production Structure, Harvard University Press, Cambridge, Massachusetts, 
74. LANDAU D. [1986], «Government Expenditure and Economic Growth in Less Developed

75. LEVINE R. and RENELT D. [1992], "A Sensitivity Analysis of CrossCountry Growth Regressions", American Economic Review, Vol. $82, N^{\circ} 4$, p. 942-963.

76. LICHTENBERG F .R. [1992], « R\&D Investment and International Productivity Differences»,National Bureau of Economic Research Working Paper, $\mathrm{N}^{\circ}$ 4161. Limited, $296 \mathrm{p}$.

77. LUCAS R. E. Jr (1977), « Understanding Business Cycles », Carnegie Rochester Conference Series on Public Policy, vol. 5, pp. 7-46. C'est dans ces articles qu'il expose sa théorie des cycles et sa fameuse critique, dite critique de Lucas

78. LUCAS R. E. Jr. and Rapping L. (1969) "Real Wages, Employment, and Inflation", Journal of Political Economy, vol. 77, pp. 721-754.

79. LUCAS R. E. Jr (1975), «Econometric Policy Evaluation: a Critique » dans K. Bruner et A. Meltzer, ed., The Phillips Curve and Labor Markets, Carnegie-Rochester Conferences Series in Public Policy, vol. 1, Amsterdam: North-Holland, pp. 19-46.

80. LUCAS, R. [1988], « On the Mechanics of Economic Development», Journal of Monetary Economics, Vol.22, p. 3-42.

81. MANKIW G. N., ROMER D. et WEIL D.N.[1992], « A Contribution to the Empirics of Economic Growth », Quarterly Journal of Economics, Vol.107, $\mathrm{N}^{\circ} 2$, p. 407-437.

82. MANSOURI B. [2003], " DéséquilibresFinanciers Publics, Investissement Privé et Croissance Economique au Maroc », Analyse Economique et Développement, Agence Universitaire de la Francophonie (AUF).

83. MATINEZ-LOPEZ D. [2005], « Fiscal Policy and Growth: the Case of Spanish Regions », Economic Issue, Vol. 10, N 1, p. 9-24.

84. MEHLUM H., MOENE K. et TORVIK R. [2006a], « Cursed by Resources or Institutions?»The World Economy, Vol.29, $\mathrm{N}^{\circ}$ 8, p.11171131.

85. MINEPAT (2013), Le Colloque sur l'exécution du BIP organisé le 20 août 2013 par le MINEPAT

86. MORLEY B. et PERDIKIS N. [2000], « Trade Liberalisation, Government Expenditure and Economic Growth in Egypt », Journal of Development Studies, Vol.36, № 4, p. 38-43.

87. MULLER P. [2005], « Esquisse d'une Théorie du Changement dans l'Action Publique ", Revue Française de Science Politique, Vol. 45, $\mathrm{N}^{\circ} 1$, p. $155-187$. 
88. MUSGRAVE R. (1959) citée par TSAFACK NANFOSSO in « 50 ans de politique économique au Cameroun » tirée dans The Theory of Public Finance, 1959.

89. MUSGRAVE R. et Musgrave Peggy, (1989) "Public Finance in

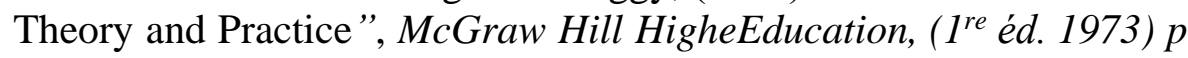
25-33.

90. MUSILA et BELASSI [2004], « the Impact of Education Expenditures on Economic Growth in Uganda: Evidence from Time Series Data», Journal of Developing Areas; Vol. 38, $\mathrm{N}^{\circ}$ 1,p. $123-133$

91. NATIONS UNIES (2007), Objectifs du Millénaire pour le Développement. New York:

92. NUBUKPO K. (2007), « Dépenses Publiques et Croissance des pays del'Union économique et monétaire ouest-africaine », Afrique Contemporaine, Vol. 2, No. 222, pp. 223 -250.

93. OJO O. and OSHIKOYA T. (1995), « Determinants of long term growth: some African results », Journal of African Economies, Vol. 4, $\mathrm{N}^{\circ} .2$, p. $163-191$.

94. OTT A.F. [2002], The public sector in the global economy, Edward Elgar Publishing

95. OUATTARA W., (2007), « Dépenses Publiques, Corruption et Croissance Économique dans les Pays de l'Union économique et monétaire ouest-africaine (UEMOA) : une Analyse de la p. 234 -240.

96. PAQUET A. (1952), «Le conflit historique entre la Loi des Débouchés et le principe de demande effective ", Thèse Doctorat, Paris

97. PUGON M., (2006), « The Service Paradox and Endogenous Economic Growth », Structural Change and Economic Dynamics, Vol. 17, N¹, p. $99-115$.

98. PYHR P., (1970) «A Zero Base Budgeting », Harvard Business Review, novembre décembre

99. RAM R., (1986), « Government Size and Economic Growth: a New Framework and Some

100. REINIKKA R. et SVENSSON J. (2004), « Local Capture: Evidence from a Central Government Transfer Program in Uganda », Quarterly Journal of Economics, Vol. 119, No. 2, p. 679-705.

101. ROMER P.M. (1986), « Increasing Returns and Long-Run Growth», Journal of Political Economy, Vol. 94, $n^{\circ}$ 5, p. 1002-1037.

102. ROMER, P. (1990), " Endogenous Technological Change», Journal of Political Economy, Vol.98, N5, p. S71-102.

103. SAHN D.E. et YOUNGER S., (2002), « Expenditure Incidence in Africa: Microeconomic Evidence », Fiscal Studies, Vol. 21, No. 3, p. $329-347$. 
104. SAVAGE J. S., SCHLOTTMAN A. et WIMMER B. S., (2006), « The Effect of Telecom Competition and Privatization on Productivity and Growth", AEI Brookings Joint Center Related Publication 03-30, American Enterprise Institute and Brookings Institution, Washington DC.

105. SAY J. B., (1826), De L'économie politique moderne, esquisse générale de cette science, de sa nomenclature, de son histoire et de sa bibliographie, Encyclopédie progressive vol. 1 p. 217-304.

106. SAY J. B., (1828), Discours d'ouverture au cours économie industrielle, dans Say [1848], p. 148-161.

107. SAY J. B., (1828-1829), « Cours complet économie politique pratique », L'économie des sociétés, Guillaumin et Cie (1852).

108. SAY J.B., (1820), Lettres a M. Malthus sur différents sujets économie politique, notamment sur les causes de la stagnation générale du commerce, Bossange ${ }^{18}$.

109. SAY J.B., (1848), Euvres diverses de Jean-Baptiste Say, Guillaumin.

110. SCHUMPETER J., (1883-1950), Théorie de l'évolution économique, première édition 1911, deuxième édition 1926.

111. SCHUMPETER J., (1951), Capitalisme, socialisme et démocratie, Payot.

112. SCHUMPETER J., (1954), histoire de l'analyse économique, publié à titre posthume 1954 .

113. SOLOW R. M., (Aug., 1957), « Technical Change and the Aggregate Production Function », The Review of Economics and Statistics, vol. 39, No. 3. n ${ }^{\circ}$ 1, 1956, p. 312-320.70

114. SOLOW Robert M. (Aug., 2002), «Peut-on recourir à la politique budgétaire ? Est-ce souhaitable ? », Revue de l'OFCE, vol. 83 $\mathrm{n}^{\mathrm{o}} 1,1956$

115. SOLOW Robert M., (1956) «A Contribution to the Theory of Economic Growth », Quarterly Journal of Economics, vol. 70, n ${ }^{\circ}$ 1, p. 65-94

116. SOLOW Robert M., (2000), Growth Theory: An Exposition, Oxford University Press,

117. SOLOW S., (1956), «A Contribution to the Theory of Economic Growth », Quarterly Journal of Economics, Vol. 70, No. 1, p. $65-94$.

118. STUARD MILLS J., (1848), Principes d'économie politique 119. STUARD MILLS J., (1861), L'utilitarisme (Utilitarianism) 120. STUARD MILLS J., (1843), Système de logique déductive et inductive 
121. STUARD MILLS J., (1861), Considérations sur le gouvernement représentatif(Considerations on Representative Government), essai sur le "moralité constitutionnelle"5

122. TANG, CHOR FOON (2010), " An Examination of the Government Spending and Economic Growth Nexus for Malaysia Using the Leveraged Bootstrap Simulation Approach »,Global Economic Review, Vol.38, N², p.215-227.

123. TANG, TUCK CHEONG (2001), «Testing the Relationship between Government Expenditure and National Income in Maylasia », Analysis, Vol.8, $N^{\circ} 1-2$, p. 37-51.

124. TANZI V. et ZEE H. (1997), « Fiscal policy and long-run growth », IMF Staff Papers, Vol. 44, p. 179 -209.

125. TENOU K [1999], « Les Déterminants de la Croissance à Long Terme dans les Pays de l'UEMOA, Notes d'Information et Statistiques », Etudes et Recherches, N. 493, BCEAO.

126. TSAFACK NANFOSSO R. (2007), Budget et politique économique en Afrique Editions, Clé, Yaoundé, Juin, 143 pages.

127. TULLOCK G., (1961), « An Economic Analysis of Political Choice », II Politics, Vol. 16,

128. ULMANN B. P., (2003) :« Economie de la Santé : Quelques Faits Stylisés », Econ WPA HEW Series.

129. VENTELOU B., (2002), « Corruption in a Model of Growth: Political Reputation, Competition and Shocks », Journal of Public Choice, Vol. 110, Nº 1-2, p. $23-40$.

130. WAGSTAFF A., (2002), « Health Spending and Aid as Escape Routes from the Vicious Circle of Poverty and Health » HNP Discussion Paper, World Bank, Washington, DC

131. WARD, Cochran A. E, DAVIS D.R., PENUBARTI M. and RAJMAIRA S., (1992), «Economic Growth, Investment, and Military Spending in India», in Chan S. et A. Mint z eds., Defense, Welfare, and Growth, Rout ledge, p. 119-136.

132. WDI, (2016), World Development Indicator report 


\section{APPENDIX}

$\underline{\text { Figure } 2}$ : Impulse response functions

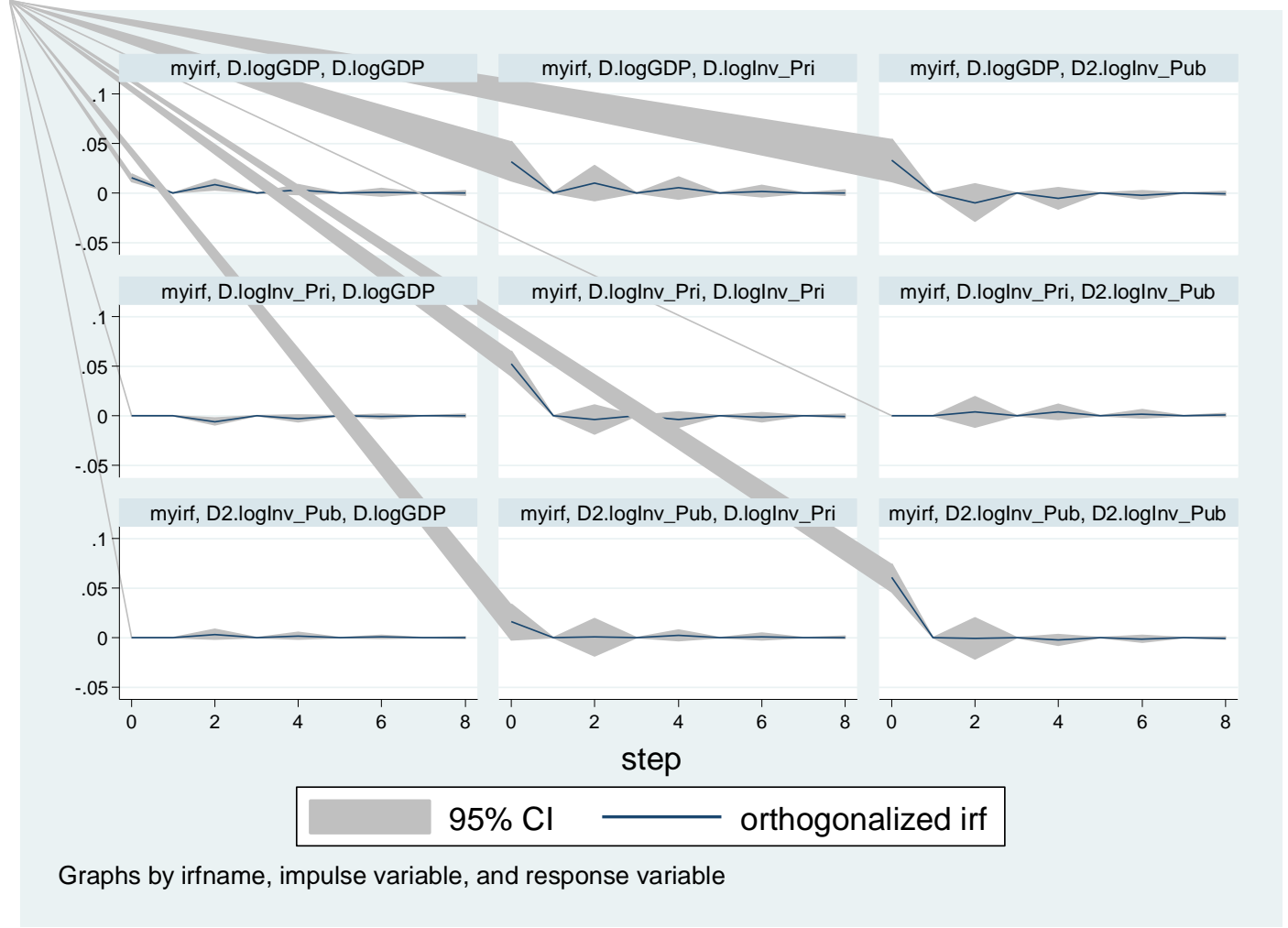

Source: Authors using Stata 13 and WDI 2016.

Table 7: Analysis of the stability of the VAR model

Eigenvalue stability condition

\begin{tabular}{|c|c|}
\hline Eigenvalue & Modulus \\
\hline$-.5182223+. .1159943 i$ & .531045 \\
$-.5182223-. .1159943 i$ & .531045 \\
$.5182223+.1159943 i$ & .531045 \\
$.5182223-.1159943 i$ & .531045 \\
$-4.239 e-17+.04001473 i$ & .040015 \\
$-4.239 e-17-.04001473 i$ & .040015 \\
\hline
\end{tabular}

All the eigenvalues lie inside the unit circle. VAR satisfies stability condition.

Source : Authors using Stata 13 and WDI 2016. 
Figure 3 : Analysis of the stability of the VAR (1) model

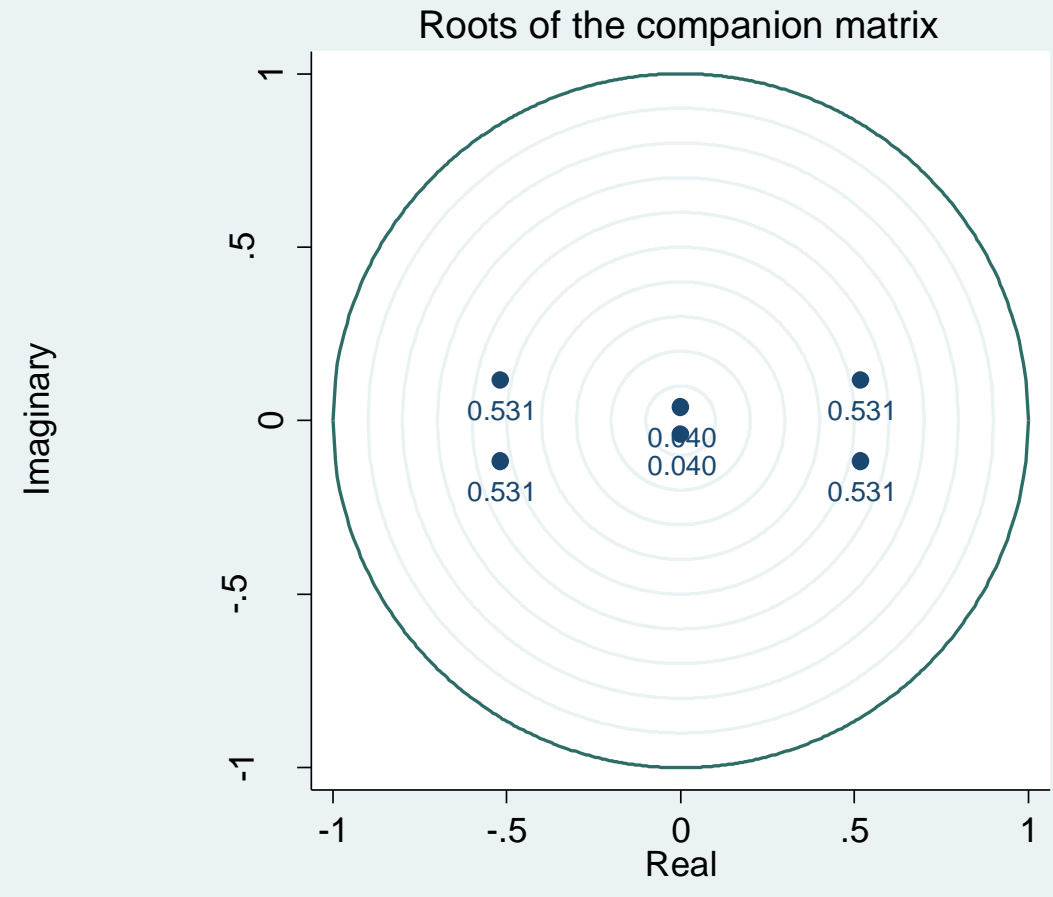

Points labeled with their moduli

Source : Authors using Stata 13 and WDI 2016.

$\underline{\text { Unit roots tests }}$

Logarithm of GDP

Selection-order criteria

Sample: 1979 - 2015

Number of obs

\begin{tabular}{|c|cccccccc|}
\hline $\operatorname{lag}$ & LL & LR & df & p & FPE & AIC & HQIC & SBIC \\
\hline 0 & 27.9407 & & & & .013649 & -1.45626 & -1.44091 & -1.41272 \\
1 & 91.8754 & 127.87 & 1 & 0.000 & .000455 & -4.85813 & -4.82743 & -4.77105 \\
2 & 96.9376 & 10.125 & 1 & 0.001 & .000365 & -5.07771 & -5.03166 & $-4.94709 *$ \\
3 & 97.0449 & .21452 & 1 & 0.643 & .000383 & -5.02945 & -4.96806 & -4.8553 \\
4 & 99.9226 & $5.7554 *$ & 1 & 0.016 & $.000347 *$ & $-5.13095 *$ & $-5.0542 *$ & -4.91326 \\
\hline
\end{tabular}

Endogenous: $\log$ GDP

Exogenous:_cons

Source: Author using Stata 13 and WDI 2016. 
Phillips-Perron test for unit root $\begin{array}{lr}\text { Number of obs }= & 40 \\ \text { Newey-West lags }= & 4\end{array}$

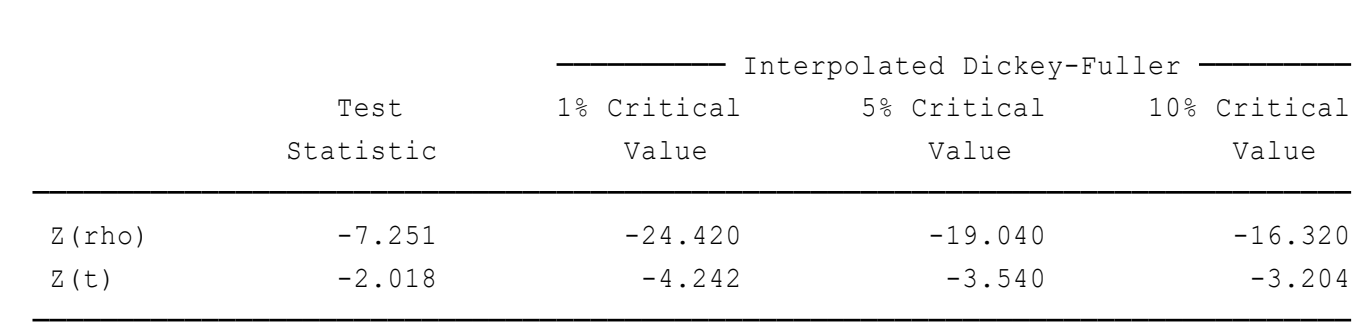

Mackinnon approximate $\mathrm{p}$-value for $\mathrm{Z}(\mathrm{t})=0.5917$

\begin{tabular}{r|rrrrrr}
\hline \multicolumn{1}{l|}{ logGDP } & Coef. & Std. Err. & $t$ & P $|t|$ & [95\% Conf. Interval] \\
\hline logGDP & & & & & & \\
L1. & .901273 & .0624846 & 14.42 & 0.000 & .7746671 & 1.027879 \\
trend & .0009088 & .0007501 & 1.21 & 0.233 & -.0006111 & .0024287 \\
- cons & 1.076627 & .6701481 & 1.61 & 0.117 & -.2812219 & 2.434476 \\
\hline
\end{tabular}

Source : Auteur à partir de Stata 13 et WDI 2016. 